\title{
Disease on Nursery Stock as Affected by Environmental Factors and Seasonal Inoculum Levels of Phytophthora ramorum in Stream Water Used for Irrigation
}

\author{
S. A. Tjosvold and D. L. Chambers, University of California Cooperative Extension, 1432 Freedom Blvd., \\ Watsonville, CA; S. T. Koike, University of California Cooperative Extension, 1432 Abbott St., Salinas, CA; and \\ S. R. Mori, USDA Forest Service Pacific Southwest Research Station, Albany, CA
}

\begin{abstract}
Tjosvold, S. A., Chambers, D. L., Koike, S. T., and Mori, S. R. 2008. Disease on nursery stock as affected by environmental factors and seasonal inoculum levels of Phytophthora ramorum in stream water used for irrigation. Plant Dis. 92:1566-1573.

A pear bait monitoring system was used to detect and quantify Phytophthora ramorum propagules in streams that flow through woodland areas with sudden oak death in Santa Cruz County, CA from 2001 to 2007. Stream propagules were detected most frequently or occurred in highest concentrations in winter and spring. The stream propagule concentration was characterized with statistical models using temperature and rainfall variables from 2004 to 2007. The highest concentrations of propagules occurred when stream sampling was preceded by about 2 months with low maximum daily temperatures and by 4 days with high rainfall. The occurrence of propagules in streams in the summer was mostly associated with infected leaves from the native host Umbellaria californica that prematurely abscised and fell into the water. When the stream water was used for irrigating rhododendron nursery stock from 2004 to 2007, disease occurred only three times in the two wettest springs (2005 and 2006) on plants sprinkler irrigated with stream water with relatively high concentrations of propagules. Disease incidence was described with a statistical model using the concentration of infective propagules as measured by pear baiting and consecutive hours of leaf wetness measured by electronic sensors at rhododendron height. The concentration of infective propagules was significantly reduced after water was pumped from the stream and applied through sprinklers.
\end{abstract}

Phytophthora ramorum is the causal agent of the disease known as sudden oak death (SOD). The pathogen causes trunk cankers and widespread mortality on tanoak (Lithocarpus densiflorus) and oak (Quercus spp.) (19), and leaf spots and blights on numerous other native hosts in California and Oregon woodlands (1,5). The pathogen was described as a new Phytophthora species in 2001, but it was observed as early as 1993 to cause leaf blights and mortality on rhododendron and viburnum in nurseries and public gardens in Germany and the Netherlands (27). With the recognition that this newly identified pathogen caused SOD, intensive nursery stock and public garden inspections ensued, and $P$. ramorum was found in several European countries. In December 2000, $P$. ramorum was first discovered infecting rhododendron nursery stock in California (8). By 2003, agricultural inspectors found the pathogen infecting nursery stock in California, Oregon, Washington, and British Columbia, Canada. In 2004, the disease

Corresponding author: S. A. Tjosvold

E-mail: satjosvold@ucdavis.edu

Accepted for publication 5 August 2008.

doi:10.1094/PDIS-92-11-1566

(C) 2008 The American Phytopathological Society became a national concern when a large wholesale nursery in California shipped camellia plants infected with $P$. ramorum to nurseries and other customers in 40 states. Presently, the Animal and Plant Health Inspection Service (APHIS) Plant Protection and Quarantine (PPQ) Agency lists 110 plant taxa as proven or associated hosts (1). There are various state, federal, and international quarantine restrictions placed on the movement of plants or plant parts of these listed hosts.

Once propagules are produced by Phytophthora spp. in natural environments, they can be moved from affected drainages through rain, runoff, and in streams as well as other means $(7,18)$. Perennial and intermittent streams often run through areas of high incidence of SOD in California and Oregon woodlands, and $P$. ramorum has been detected in these streams $(6,24)$. tion by nurseries and landowners, and consequently propagules might be pumped from streams, moved through irrigation systems, and dispersed onto nursery or landscape hosts.

There are many important factors that should be understood to manage the risk involved with using contaminated irrigation water in a nursery or landscape. It is important to have an effective method to detect and quantify propagules in the stream and to understand the environStream water is sometimes used for irriga- mental conditions that are favorable to disease when stream propagules are present. We first monitored for the presence of $P$. ramorum propagules for over a year in several local streams flowing through areas where there was a high incidence of SOD to determine the general distribution of infested streams. Then for more than 4 years, we monitored propagule presence and concentration in one of these infested perennial streams. Concurrently, rhododendrons in an experimental layout that simulated nursery conditions were irrigated when needed with this stream water and noninfested domestic water. Each water source was applied with sprinkler and drip irrigation methods. The results from experiments will help determine the usefulness of stream baiting to detect and quantify propagules in streams and to assess the risk involved in irrigating with contaminated stream water, and provide information for the development of nursery management practices to control this disease.

\section{MATERIALS AND METHODS}

Pear baiting of stream samples to detect and quantify propagules. For the stream survey (2001 to 2002) and irrigation experiment (2004), the stream water sample was collected and baited with two green (unripe) D'Anjou pears. Pears were purchased as needed in small lots and stored under refrigeration until used. For the irrigation experiment (2005 to 2007), each of the three 8-liter stream water samples was baited with three pears. First, the pears were washed with liquid dishwashing detergent, rinsed, and allowed to dry. The pears were then suspended in each water sample so that half of each pear was submerged in the water by means of plastic bird netting secured to the bucket with elastic cords. The pears were incubated in the water samples for $24 \mathrm{~h}$ and then gently rotated to expose the entire pear to the water samples that potentially contained propagules. After another $24 \mathrm{~h}$, the pears were removed from the water and placed on absorbent paper towels for an additional 48 to $72 \mathrm{~h}$ at a mean temperature of $20^{\circ} \mathrm{C}$ in open air and natural light. After some experience with subculturing, lesions caused by Phytophthora species could easily be separated from those lesions caused by Pythium species (as described in Results section). Tissue from the margin of 
each discrete lesion caused by Phytophthora species was transferred to $10-\mathrm{cm}$ petri dishes containing pimaricinampicillin-rifampicin-pentachloronitrobenzene selective agar (PARP) (7). Those colonies with the characteristic morphological features of $P$. ramorum were counted. For the stream survey (2001 to 2002) and 2004, only the presence or absence of $P$. ramorum in the water sample was recorded. For 2005 to 2007, the number of lesions that produced $P$. ramorum colonies on PARP - and therefore an estimate of the number of infective propagules-was determined on each of the three pears and three water samples. By having multiple pear baits in each water sample, a standardized volume of stream water, and a consistent laboratory incubation environment, the concentration of infective propagules was determined for each water sample (infective propagules/ pear/liter).

Survey of local streams for the presence of propagules. From April 2001 to April 2002, stream water was sampled weekly for the presence of $P$. ramorum propagules in seven rivers and creeks in Santa Cruz County, CA. The area of the study encompasses multiple types of mixed evergreen forests characterized by a Mediterranean climate, with cool, wet winters and hot, dry summers. The geography captures rainfall into the following four primary watershed basins: the San
Lorenzo River $\left(275 \mathrm{~km}^{2}\right)$, Soquel Creek $\left(83 \mathrm{~km}^{2}\right)$, Aptos Creek $\left(65 \mathrm{~km}^{2}\right)$, and Corralitos/Salsipuedes creeks $\left(72 \mathrm{~km}^{2}\right)$. All major watersheds, along with some tributaries, were represented in this study, including Lompico Creek, near Felton, CA, which later became the water source for the irrigation experiment. All streams were perennial except Bean Creek, which dried in late spring. All northern streams drained through woodland known to contain SOD. California bay (Umbellaria californica) was a common infected native host in these watersheds. The two most southern streams, Corralitos and Aptos creeks, drained through woodland that contained hosts of SOD, but the pathogen had not been confirmed in those regions (Fig. 1). The samples were taken mostly well downstream from the suspected diseased watersheds. At some sampling sites, hosts of $P$. ramorum were visible. The samples were taken and transported to a laboratory and evaluated for the presence and concentration of $P$. ramorum as described earlier.

Irrigation experimental site and plant material. Experimental site. All irrigation experiments were conducted on a parcel of private land adjacent to Lompico Creek in Felton, CA. Lompico Creek drains a heavily SOD-infested watershed (Fig. 1). Infected hosts were visible from the point where the stream sample was taken.

Plant material. All experimental plants consisted of well-established 3.8-liter con- tainerized rhododendrons, Rhododendron 'Cunningham's White', obtained from a commercial nursery in one large lot at the beginning of each of the 4 year's experiments. Plant height (including container) varied somewhat with annual lots, but ranged from 40 to $80 \mathrm{~cm}$. Plants were maintained without the use of fungicides under $40 \%$ shade cloth, fertilized with 6 g/pot slow release fertilizer (21-5-6 Apex, J.R. Simplot) every 4 months, and irrigated when needed based on environmental demand.

Irrigation experiments and layout. Experimental treatments. There were four experimental periods in 2004, 2005, 2006, and 2007 (until July), each beginning in January with new rhododendrons placed in experimental plots. The nearby stream (Lompico Creek) was sampled weekly or biweekly, and samples were evaluated for the presence and/or concentration of $P$. ramorum propagules with the baiting techniques described earlier. Each year, the experiment used a randomized complete block experimental field design; there were six blocks, each treatment plot consisting of three rhododendrons spaced approximately $13 \mathrm{~cm}$ apart. Each treatment plot grouping was arranged in the center of a $95 \times 82 \times 16 \mathrm{~cm}$ (height) wooden pallet spaced $1 \mathrm{~m}$ apart. This arrangement eliminated pot contact with the soil and rain splash onto foliage from the soil. When plants required water, the plants in the

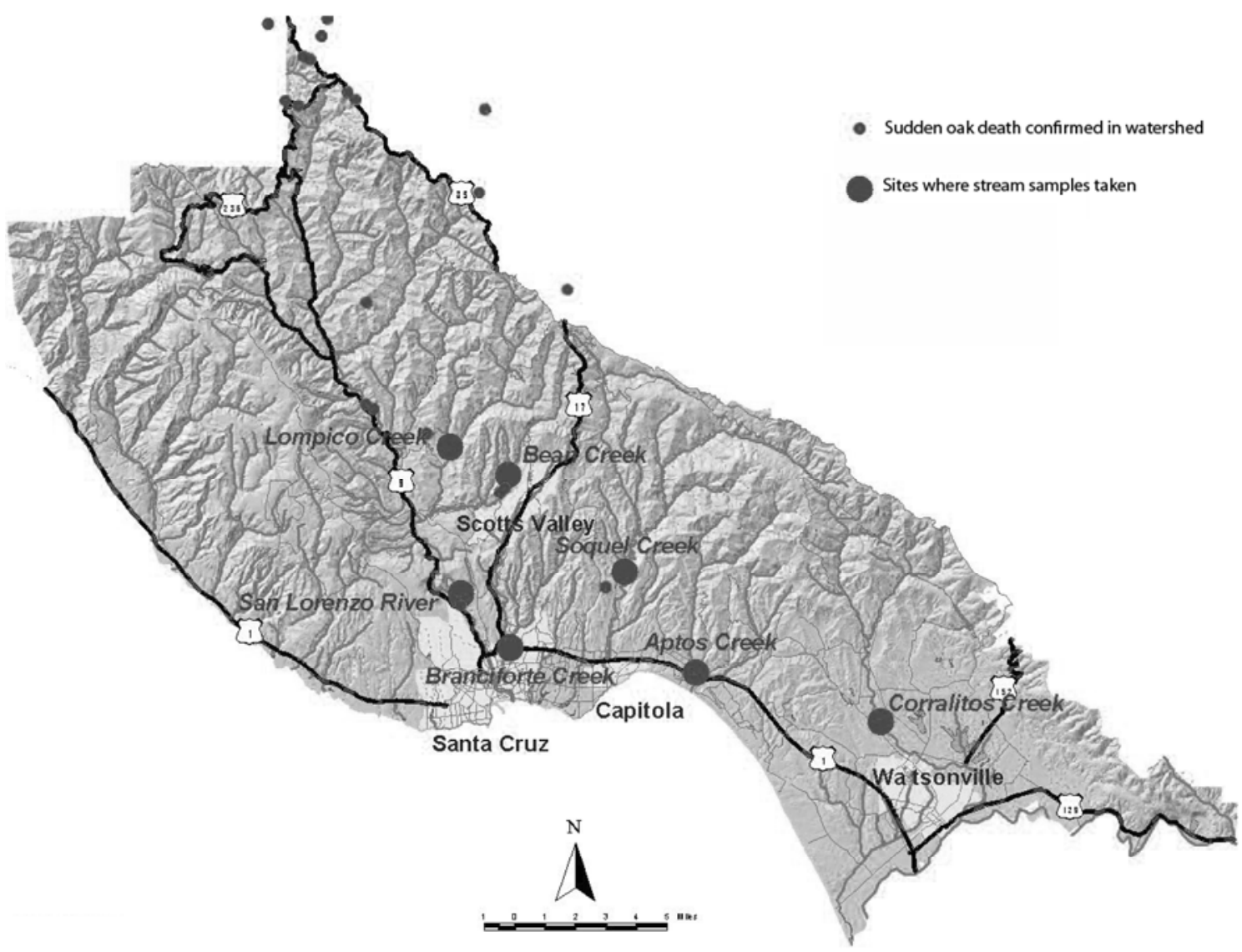

Fig. 1. Locations of stream sampling sites for Phytophthora ramorum and confirmed locations with sudden oak death in Santa Cruz County, CA. 
experimental plot were irrigated with the appropriate irrigation treatment: (i) domestic water applied with sprinkler irrigation, (ii) domestic water applied with drip irrigation, (iii) stream water applied with sprinkler irrigation, and (iv) stream water applied with drip irrigation.

Water sources. The experiments received natural rainfall and in dry periods were irrigated with water supplied from either domestic or stream water. Domestic water (chlorinated at 0.3 to $0.7 \mathrm{ppm}$ ) was plumbed off of a nearby water supply originating from the local San Lorenzo Water District. Stream water was pumped from the nearby perennial stream (Lompico Creek) with a $560 \mathrm{~W}$ electric impellor pump and filtered at the pump through a fiberglass window screen and sediment filter. The water was pumped from the stream at an initial pressure of 525 to 595 $\mathrm{kPa}(75$ to $85 \mathrm{psi})$ through a $1.9-\mathrm{cm}$ black poly tube for approximately $200 \mathrm{~m}$ upslope to the irrigation experiment where the irrigation systems operated at 245 to 280 $\mathrm{kPa}$ (35 to $40 \mathrm{psi}$ ).

Irrigation methods. Each sprinkler irrigation plot utilized brass nozzle sprinkler heads (Champion SF-9, $140 \mathrm{kPa}$ [20 psi], 6 liters/h) on inverted "J" shaped risers allowing the sprinkler heads to be installed upside down and therefore restricted water application to the foliage and pots of the experimental plot. Drip irrigation plots utilized pressure compensated drippers (Pepco \#12503117, 1.9 liters/h/plant), and water was applied directly to the soil and not to the foliage. Irrigations were made when approximately half the available soil water had been used by the plant as measured by a gravimetric method. Water was applied until container capacity was reached and an additional 20\% leaching fraction was added. On average, this took approximately $45 \mathrm{~min}$ for sprinkler and $1 \mathrm{~h}$ for drip irrigations.

Occurrence and concentration of propagules in stream water. Stream survey. One 8.0-liter water sample was collected weekly from April 2001 to April 2002 from each of the seven selected streams and transported on the same day to our local laboratory in Watsonville, CA for processing.

Irrigation experiment. Three 8.0-liter samples were collected approximately biweekly in 2004 and weekly from January 2005 to July 2007 from Lompico Creek near Felton, CA near the point where the stream water was pumped for the stream irrigation treatments. To assess if there was any loss of propagule viability as the stream water was pumped from the stream to the sprinkler-irrigated plants, three additional 8.0-liter stream water samples were collected by dipping the running sprinkler heads into the collection buckets from 1 April 2005 to 20 October 2006.

Samples were collected in 13.3-liter polyethylene buckets that had been disin- fected with $70 \%$ ethanol and then triplerinsed in the source water before sampling. Water samples were collected by dipping the container carefully into the surface of the stream to help exclude plant matter and other debris from the sample. The infective propagules present in the stream water were determined with pear baiting as described earlier for both stream and sprinkler locations.

Evaluation of disease incidence and severity in irrigation experiments. Every 2 weeks, the rhododendrons in the experimental plots were monitored for disease symptoms. Leaf lesions characteristic of that caused by $P$. ramorum were removed and plated on PARP and incubated in the dark at a mean temperature of $20^{\circ} \mathrm{C}$ for identification. The number of infected plants and infected leaves on each plant were recorded for each observation date for each treatment plot.

Environmental monitoring and correlation with disease and $P$. ramorum in streams. Rainfall (mm), ambient temperature $\left({ }^{\circ} \mathrm{C}\right)$, and leaf wetness $(\%)$ (after 2004) at plant height were measured at the Lompico Creek/irrigation experimental site with digital sensors (respectively SRGA-M002, S-TMB-M002, and S-LWAM003, and recorded on either H21-001 or 002 data loggers, Onset Computer Co., Pocasset, MA).

Statistical analysis. Comparing infective propagules in stream and sprinkler irrigation water. The infective propagule counts were analyzed with Poisson regression models from the family of the generalized linear models (GLM) for overdispersed Poisson distributed responses (counts) to address potential overdispersion arising from the day effect (12). Treatment, year, and treatment-year interaction were explanatory variables:

Expected $\left[\right.$ propagules/pear/liter_count $\left.t_{t, y, j(y)} \mid \varepsilon_{j(y)}\right]$ $=e^{\text {Treat }_{t}+\text { Year }_{y}+\text { Treat }^{*} \text { Year }_{\mathrm{ry}}+\varepsilon_{j}(y)}$

where $t=1,2(1=$ stream, $2=$ sprinkler $)$ and $y=1,2(1=$ year $2005,2=$ year 2006), $j(y)=$ Julian day nested in year, $\varepsilon$ is the overdispersion error due to the day effect (three samples per sampling Julian day), and " $"$ means "conditioned to". The maximum likelihood estimation (MLE) technique was used to estimate the model's parameters with SAS (v. 9.1.3) NLMIXED procedure, and the likelihood ratio test was applied to make the statistical comparisons (21).

An explanatory model for the concentration of infective propagules in stream water. The model's explanatory variables were functions of daily temperature $\left({ }^{\circ} \mathrm{C}\right)$ and daily rain $(\mathrm{mm})$ from periods prior to sampling dates.

The stream infective propagule counts (infective propagules/pear/liter) were analyzed with the GLM Poisson regression models for over-dispersed Poisson distrib- uted responses (counts) to address potential overdispersion arising from unknown sources. The candidate for the temperature explanatory variable was related to the time period: (i) temperature (daily average or maximum ${ }^{\circ} \mathrm{C}$ ) for all the days in a given daily interval prior to the sampling day, or (ii) temperature (daily average or maximum ${ }^{\circ} \mathrm{C}$ ) for the first 7 days for a given interval prior to the sampling day. The candidate for the explanatory rain variable was related to time period: (i) daily average $(\mathrm{mm})$ of a given daily interval prior to the sampling day, or (ii) the daily average $(\mathrm{mm})$ of the first day of a given daily interval prior to the sampling day.

The statistical model is:

Expected $\left[\right.$ propagules/pear/liter_count $\left._{i} \mid \varepsilon\right]=$

$e^{\text {Temperature_effect }_{i}+\text { Rain_effect }_{i}+\varepsilon}$

where $i=1$ to total number of days since the experiment start, "" means "conditioned to", and $\varepsilon$ is the overdispersion error.

Temperature-effect $=$ Aver_temp $=$

$\frac{\sum_{d=\text { ndays }}^{1} \text { Temperature }_{d}}{\text { ndays }}$ or

Temperature-effect $=$ Aver7_temp $=$

$\frac{\sum_{d=\text { ndays }}^{\text {ndays-7 }} \text { Temperature }_{d}}{7}$,

Rain-effect $=$ Aver_rain $=$

$\frac{\sum_{d=\text { ndays }}^{1} \text { Rain }_{d}}{\text { ndays }}$ or

Rain-effect $=$ Back_rain $=$ Rain $_{\text {ndays }}$

The choice of the functions of temperature and rain as candidate explanatory variables were based on exploratory analyses and known biological parameters of $P$. ramorum. The models' parameters were estimated with the SAS (v. 9.1.3) GENMOD procedure (21). The best model was selected using the Akaike QAIC criterion (3). The significance of the explanatory variables (temperature and rain) was evaluated by their $P$ values and the sign of the coefficient.

An explanatory model for disease incidence. Disease incidence (number of plants with foliar infection) was analyzed with the GLM Poisson regression models for over-dispersed Poisson distributed responses (counts) to address potential overdispersion arising from unknown sources. The two candidates for explanatory variables were (i) the maximum number of stream infective propagules (propagules/pear/liter) selected from the actual spline-smoothed data during the selected irrigation period prior to the disease evaluation date, and (ii) the maximum number of consecutive hours with leaf wetness less than a given percent $(50,10$, and $5 \%$ ) and within a given temperature 
minimum $\left(2\right.$ or $\left.5^{\circ} \mathrm{C}\right)$ and maximum $(12$ or $20^{\circ} \mathrm{C}$ ) on the selected irrigation date having the maximum propagule concentration. Periods of 7, 14, 21, and 28 days prior to the disease evaluation date were tested, and leaf wetness hours and temperatures for periods ( 2 or 3 days) at each irrigation date prior to the disease evaluation date. Leaf wetness and temperature periods were "shifted" to begin on the selected irrigation date at 6 P.M. This facilitated testing the models using data during a period where the greatest number of consecutive "wet" leaf wetness hours would be expected, which was during the evening and night period.

The statistical model is:

Expected $\left[\right.$ plant_disease_count $\left._{i} \mid \varepsilon_{i}\right]=$

$e^{\text {\#leafwet_hours } i_{-}+\text {max_propagules/ pear } / \text { liter } r_{i}+\varepsilon_{i}}$

The choice of the functions as candidate explanatory variables was based on exploratory analyses and known biological parameters of $P$. ramorum, where $i=1$ to total number of days since the experiment start, "|" means "conditioned to", and $\varepsilon$ is the overdispersion error. The periodic spline-smoothing of the maximum number of stream infective propagules was done with the $\mathrm{R}$ bs.per.ek function (15). The model's parameters were estimated with the GENMOD procedure (21). The best model was selected using the Akaike QAIC criterion (3).

\section{RESULTS}

Occurrence of propagules in local streams. Necrotic lesions on baited pears resulting from Phytophthora and Pythium spp. infections had distinctive characteristics, and they easily could be separated visually. Lesions caused by Phytophthora species were firm, often diffuse, and in a rosette pattern. Lesions caused by Pythium species were soft, not diffuse, sunken, often with a broken skin, and comparatively fast-growing. All Phytophthora-like lesions that were not contaminated with other organisms were subcultured, and $P$. ramorum was identified in approximately $90 \%$ of the isolates from those lesions. Other Phytophthora isolates were not identified to species.

$P$. ramorum was detected during the survey period (April 2001 to April 2002) in all streams except the two most southern streams, Corralitos Creek and Aptos Creek. These two streams were the only ones sampled where $P$. ramorum had not been confirmed in their watersheds (Fig. 1). The pathogen was regularly detected during the period following the beginning of winter rainfall and through early spring (January 2002 through March 2002). It was only detected once in the San Lorenzo River during the characteristic warm, dry summer months of the survey period following a relatively long and heavy thunderstorm (18 September 2001) in the river's drainage (Table 1).

Disease occurrence and concentration of propagules in stream water used for irrigation. 2004. Propagules were regularly detected during the rainy winter and early spring (December 2003 to April 2004) with the two-pear baiting method in Lompico Creek with single water samples. Later, in dry conditions (23 May and 23 June), it was detected after infected California bay leaves were blown into the stream by unusually strong winds (10 to 11 May). Rhododendron nursery stock required the first irrigation on 13 February. The spring was unusually dry and warm, and consequently regular irrigations were required beginning in early March. No disease was detected in any of the irrigation treatment plots (Fig. 2).

2005. Propagules were detected during most of the year in Lompico Creek with the more robust baiting system (three pears in each of three water samples). There were high concentrations of propagules detected during the winter to late spring, which were associated with rainy periods. Rhododendron nursery stock was irrigated beginning 4 February and intermittently between rains as required. Leaves infected with $P$. ramorum were detected on the shaded or lower foliage 22 April only on rhododendrons sprinkler irrigated with stream water (Fig. 2).

2006. As in 2005, propagules were detected most of the year in the stream with the more robust baiting system. Again, there were high concentrations of propagules detected during the winter to late spring. Some of the highest concentrations of propagules recorded for the entire 4 years were detected from March to May during the unusually wet late spring. Rhododendrons did not require the first irrigation until 12 May. Leaves infected with $P$. ramorum were detected on the shaded or lower foliage 26 May and 23 June only on rhododendrons sprinkler irrigated with stream water (Fig. 2).

2007. As with previous years, there were relatively higher concentrations of propagules in the spring. Propagules were detected until just before the experiment was concluded 1 July 2007. This was a relatively dry spring with little appreciable rainfall after the end of February. Rhododendron stock was regularly irrigated beginning 27 February. No disease was detected in any of the irrigation treatment plots (Fig. 2).

Propagule concentration after pumping and application with sprinklers. When propagules were detected in the stream, they were also detected in the stream water after it had been pumped from the stream, moved through the irrigation pipe, and applied at the sprinkler heads. However, when the levels were compared in 2005 and 2006, the irrigation water samples significantly contained $39 \%$ fewer viable propagules than were found directly from the stream ( 0.09 versus 0.23 , respectively, mean infective propagules/ pear/liter $)(P<0.0001)$ (Fig. 3).

An explanatory model for stream inoculum concentration. There was a strong association of temperature and rainfall amounts to the stream propagule concentration (Fig. 2). Statistical modeling helped determine the relationship of time to those environmental parameters. The best model to explain the stream propagule concentration (lowest $\mathrm{QAIC}_{\mathrm{c}}$ ) used the mean maximum temperature in a 7-day period, 62 to 68 days, prior to sampling and the mean daily rainfall 4 days prior to the sampling date:

Stream propagules $=e^{4.8+0.049 \text { Rain }-0.15 \max \text { Temp }}$

The estimated coefficients were statistically significantly different from 0 at $\alpha$ level $=0.05$, where Rain is the actual mean rainfall $(\mathrm{mm}) 4$ days prior to the stream sampling date and maxTemp is the mean maximum daily temperature $\left({ }^{\circ} \mathrm{C}\right) 62$ to 68 days prior to the stream sampling date (Fig. 4).

An explanatory model for disease incidence caused by $P$. ramorum on rhododendron irrigated with stream water by sprinklers. In the 4 years of irrigation experiments, there were only three times

Table 1. Positive detection (+) of Phytophthora ramorum in streams of Santa Cruz County, CA sampled weekly from April 2001 to April 2002

\begin{tabular}{|c|c|c|c|c|c|c|c|c|c|c|c|}
\hline Stream & $\begin{array}{c}9 \text { Apr } \\
2001\end{array}$ & $\begin{array}{c}18 \text { Sept } \\
2001\end{array}$ & $\begin{array}{c}4 \text { Jan } \\
2002\end{array}$ & $\begin{array}{c}\text { 31 Jan } \\
2002\end{array}$ & $\begin{array}{c}8 \text { Feb } \\
2002\end{array}$ & $\begin{array}{c}19 \text { Feb } \\
2002\end{array}$ & $\begin{array}{c}28 \text { Feb } \\
2002\end{array}$ & $\begin{array}{c}10 \text { Mar } \\
2002\end{array}$ & $\begin{array}{l}19 \text { Mar } \\
2002\end{array}$ & $\begin{array}{c}25 \text { Mar } \\
2002\end{array}$ & Total \\
\hline Bean Creek & + & & + & & + & & + & + & + & + & 7 \\
\hline Soquel Creek & & & & & & + & & + & & + & 3 \\
\hline Lompico Creek & & & & & + & + & & + & & & 3 \\
\hline Branciforte Creek & & & + & + & + & + & & & & & 4 \\
\hline San Lorenzo River & & + & & & & + & + & + & + & + & 6 \\
\hline Aptos Creek & & & & & & & & & & & 0 \\
\hline Corralitos Creek & & & & & & & & & & & 0 \\
\hline Total & 1 & 1 & 2 & 1 & 2 & 4 & 2 & 5 & 2 & 3 & 23 \\
\hline
\end{tabular}


that disease was detected on rhododendron, and only on those plants that were sprinkler irrigated with stream water. When disease occurred, it was found on multiple leaves of multiple plants in multiple treatment blocks. There was an association of temperature, leaf wetness, stream inoculum concentration, and irrigation date to that of disease occurrence (Fig. 2). Statistical modeling was limited since there were only three disease detections. However, the best model (lowest QAIC $_{c}$ ) used the maximum stream concentration during irrigations as one variable and maximum consecutive hours where high leaf wetness occurred ( $50 \%$ or greater) as another variable:

Number plants diseased $=$

$e^{12.2+0.26 \text { hours_LW }+9.9 \text { conc._propagules }}$

These parameters gave the best model fit when applied under conditions with a relatively cool temperature range $\left(2\right.$ to $12^{\circ} \mathrm{C}$ ) and when applied to periods 7 or 14 day before disease detection, although the best fit was for 7 days. The estimated coefficients were statistically different from 0 at $\alpha$-level $=0.05$. Conc. propagules is the maximum number of stream infective propagules (propagules/pear/liter) selected from the actual spline-smoothed data during the selected irrigation period prior to the disease evaluation date, and hours_LW is the maximum number of consecutive hours with leaf wetness 50 or greater. Using this disease explanatory model, a table

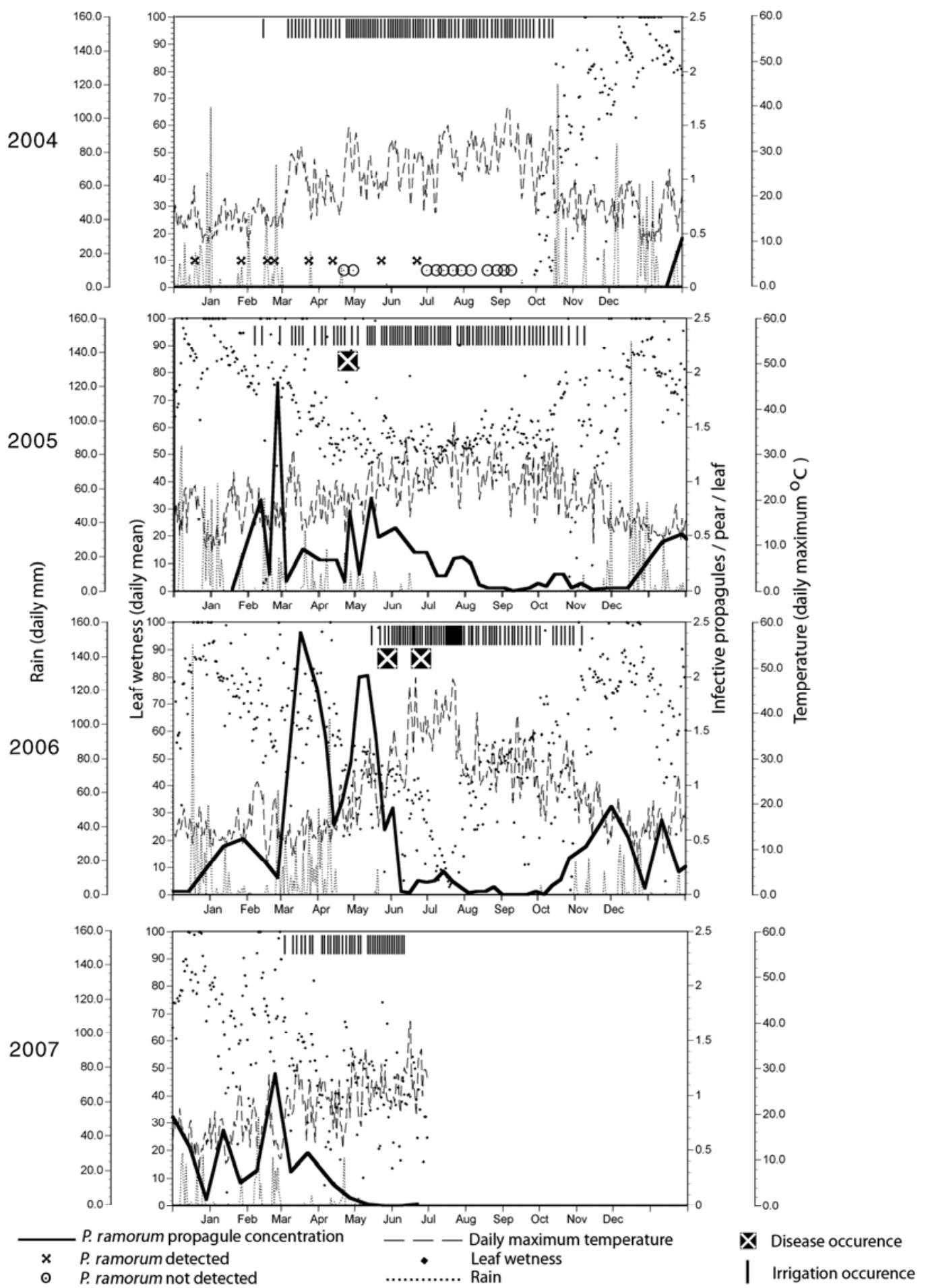

Fig. 2. Rainfall $(\mathrm{mm})$, ambient maximum temperature $\left({ }^{\circ} \mathrm{C}\right)$, leaf wetness $(\%)$, Phytophthora ramorum stream propagules (infective propagules/pear/liter), irrigation dates, and disease occurrence for each year of the experiment: 2004, 2005, 2006, and 2007. 
was developed to better illustrate how disease incidence on rhododendron was affected by different possible combinations of leaf wetness hours and propagule concentration in our experiment (Table 2).

\section{DISCUSSION}

Streams flowing through watersheds with SOD can contain viable $P$. ramorum propagules year-round. Single stream samples with two pear baits, a consistent laboratory incubation environment, and a standardized sample volume of stream water were sensitive enough to identify watersheds with or without SOD. When this monitoring system was intensifiedthree stream samples baited with three pears each-the infective propagule concentration could be estimated. For nearly 4 years, this robust pear bait monitoring system gave consistent, epidemiologically valuable data. Pear bait monitoring systems are considered to be highly useful for detecting Phytophthora species from various bodies of water in the field $(9,13,29)$ and for detecting $P$. ramorum in stream water (6). Another monitoring system using membrane filters can be sensitive in detecting and quantifying Phytophthora species in water sources $(11,17,20)$. However, membrane filters can easily become clogged by stream colloidal particles and other debris before sufficient water has been filtered for the procedure, and large numbers of propagules could be inadvertently caught by prefilters, although the selection of the filter may ameliorate this problem (10). Rhododendron leaf baits used for in-stream monitoring for $P$.

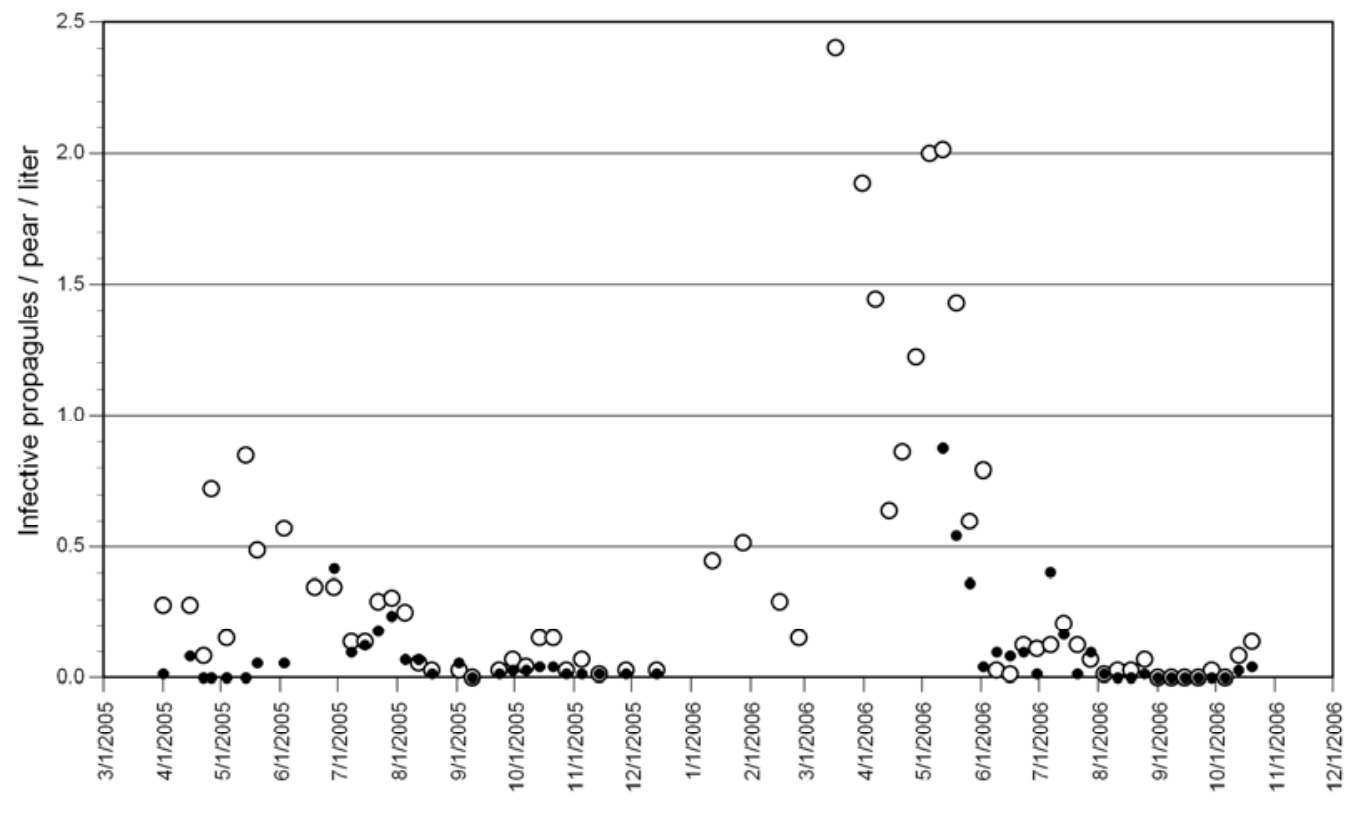

$\circ$ Stream • Sprinkler

Fig. 3. Comparison of infective propagules of Phytophthora ramorum in stream and after pumping at the sprinkler head.

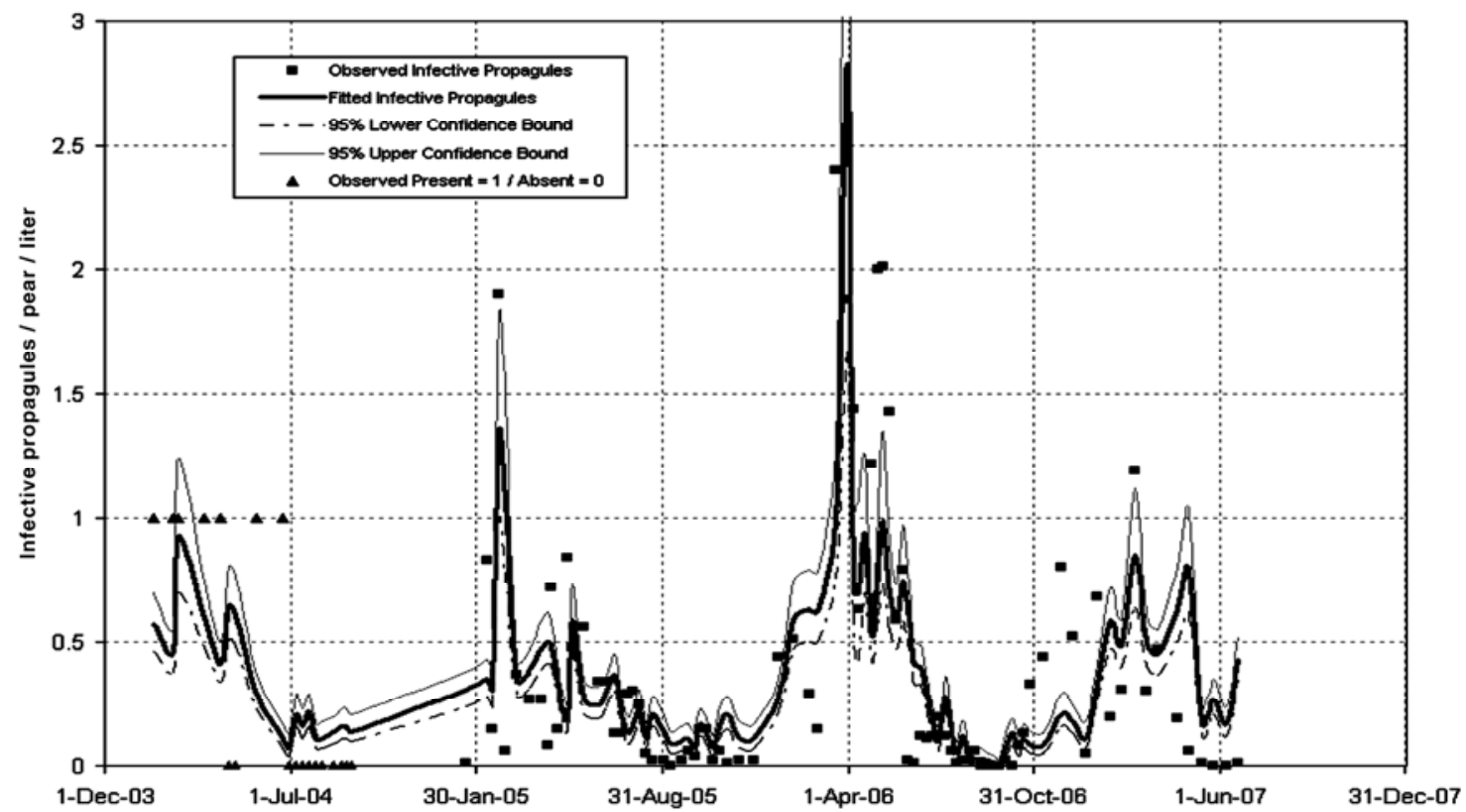

Fig. 4. Actual versus model-fitted stream propagule concentration of Phytophthora ramorum. The best mathematical model used the mean maximum temperature $\left({ }^{\circ} \mathrm{C}\right)$ in a 7 -day period, 62 to 68 days, prior to sampling and the mean daily rainfall $(\mathrm{mm}) 4$ days prior to the sampling date. 
ramorum (14) are best suited for $P$. ramorum detection (presence/absence) and not for quantification of propagules in stream water. Lesions of $P$. ramorum on rhododendron leaf baits cannot be visually distinguished from lesions caused by other water molds, and baiting in streams is not done under standardized temperature incubating conditions or with known sample volumes. All these monitoring methods, including our pear baiting method, only give results that are correlated with the total number of propagules present because, by their nature, they only detect a subset of the actual numbers of infective propagules in the stream sample. It would be informative to correlate the results obtained with this pear baiting monitoring system with known numbers of $P$. ramorum propagules in serial dilution, so that standardized levels could be equated with other standardized research projects.

Our findings of a seasonal pattern of propagule occurrence in stream water in Santa Cruz County were consistent with the presence of propagules in rainwater in a similar California mixed evergreen forest in Sonoma County, CA (6). In that study, the collection of propagules in rainwater was attributed to sporangia production from nearby California bay trees. Moreover, the period between the start of rains and the detection of relatively high levels of propagules in the winter and early spring was attributed to the breaking of the pathogen's dormancy on over-summered leaves. Our stream propagule statistical model strengthens this developmental explanation. The statistical model illustrates that stream propagule concentration is a function of a negative coefficient for the maximum temperature variable for periods about 2 months (62 to 68 days) before stream sampling. Therefore, the very cool temperatures that occur in the fall and early winter are perhaps the most important factor to break dormancy and begin vigorous pathogen development. The model does not necessarily indicate that rain is not important at that time. In fact, light rains, which are common in the fall, could be important for pathogen development and secondary infections on hosts, increasing potential inoculum sources for winter or spring. The stream propagule concentration is also a function of a positive coefficient for the rainfall variable when applied to periods up to 4 days before stream sampling. Therefore, high rainfall just preceding stream sampling perhaps could initiate sporulation, and if sufficient, wash propagules from the leaves and carry the propagules in waterways and eventually into streams.

Propagules could be detected anytime of the year with the robust pear bait monitoring system, although they were found less commonly or at low levels in the seasonal dry periods. A positive detection in the San Lorenzo River in late summer 2001 was preceded by an unusually heavy thunderstorm. This could be explained with the stream propagule statistical model, which predicts that rainfall is needed just preceding the stream sampling to detect propagules. However, propagules detected in streams in seasonal dry periods must be explained in another way, and several observations of ours and others provide a possible explanation. First, we detected propagules unexpectedly following an unusual windstorm in a dry period, 10 May 2004. Following the windstorm, we observed infested California bay leaves floating in masses in shallow pools throughout the stream. We also commonly observed infected California bay leaves and infected trees or wind-damaged branches of hosts that had fallen into the local streams during dry seasonal periods. Accelerated abscission as a consequence of $P$. ramorum infection has also been observed in several ornamental hosts $(23,25)$, and abscission of infected California bay leaves also seems to occur readily. Another study showed that flooding California bay leaves could produce abundant spores in less than $48 \mathrm{~h}$ under laboratory conditions (6). Therefore, where California bay is a ubiquitous host along or near streams, infected leaves could fall into the streams, and floating infected leaves could sporulate and produce a significant detectable level of inoculum during seasonal dry periods.

During the 4 years of irrigation experiments, disease caused by $P$. ramorum was only detected three times in the spring on rhododendrons that were sprinkler irri-

Table 2. Percent diseased Rhododendron plants as affected by stream propagule concentration of Phytophthora ramorum and consecutive leaf wetness hours as measured at plant height ${ }^{\mathrm{a}}$

\begin{tabular}{|c|c|c|}
\hline Propagules/pear/liter & $\begin{array}{l}\text { Leaf wetness hours } \\
\text { at } 2 \text { to } 12^{\circ} \mathrm{C}\end{array}$ & $\begin{array}{l}\text { Estimated percent diseased plants } \\
(95 \% \text { confidence intervals) }\end{array}$ \\
\hline 0.05 & 18 & $0(0,5.6)$ \\
\hline 0.1 & 17 & $0(0,5.6)$ \\
\hline 0.2 & 16 & $5.6(5.6,11.1)$ \\
\hline 0.3 & 15 & $5.6(0,16.7)$ \\
\hline 0.35 & 14 & $5.6(0,16.7)$ \\
\hline 0.45 & 13 & $11.1(5.6,22.2)$ \\
\hline 0.55 & 12 & $16.7(11.1,33.3)$ \\
\hline 0.65 & 11 & $27.8(11.7,50.0)$ \\
\hline 0.75 & 10 & $50.0(27.8,88.9)$ \\
\hline
\end{tabular}

a Percent diseased plants estimated from explanatory statistical model with $95 \%$ confidence intervals. gated with stream water. The important factors and interactions that are involved in disease occurrence can be demonstrated with the data for leaf wetness, temperature, stream propagule concentration, and irrigation dates over the 4 years of the irrigation experiment. In the spring, the number of propagules present in irrigation water can be sufficiently high to cause disease on rhododendrons. Disease only occurred in 2005 and 2006 when rainfall and propagules were at their highest levels. The unusually wet spring of 2006 was particularly noteworthy, as disease was detected only 14 days following the first irrigation with stream water that contained the highest levels of propagules recorded in the 4 years of the irrigation experiment. No disease occurred at other times of the year. This was probably because either the inoculum levels were too low (fall), environmental conditions were not conducive to disease development (summer), or irrigation with infested stream water was not necessary because rainfall was sufficient to meet transpiration requirements of the rhododendrons (winter).

During this study, disease occurred with a plant infection rate of $30.0 \%$ (April 2005), 22\% (May 2006), and 9\% (June 2006). Another nursery irrigation study (28) used artificially infested sprinkler irrigation water and relatively high levels of $P$. ramorum propagules (up to an estimated maximum of $3.0 \times 10^{5}$ zoospores/liter), and the maximum infection rate on rhododendrons in all experiments was less than $19 \%$. Although it is not possible to compare propagule levels of the different experiments, disease only occurred on the lower portions of the plants in both studies. This is where the longest leaf wetness periods would occur and ultraviolet radiation, which is deleterious to zoospores, would be insignificant or minimal. Although these infection rates might be considered low compared to other foliar diseases, the fact that the disease was detected in relatively obscure areas of the plant indicates that detection in a nursery could be difficult. In our experiment, leaves were removed soon after symptoms were expressed, thus limiting the source of inoculum for secondary infection, and experimental plots were separated by more than $1 \mathrm{~m}$, increasing air movement between experimental plants and aiding the drying of the perimeters of the small experimental plots. In commercial nurseries, the dense spacing and large lots of nursery stock would be expected to provide the conditions that promote secondary infections and, if left uncontrolled, a high infection rate once detected.

There was no disease detected on drip irrigated plants with contaminated stream water, indicating that propagules needed to be directly applied to the foliage, or propagules that are applied to the soil could not splash in sufficient numbers to 
the foliage, for example, with subsequent turbulent rain episodes. Root infections are possible on rhododendron when soil becomes infested with $P$. ramorum $(16,22)$. At the conclusion of the last experimental year (summer 2007), roots were sampled from six plants that received stream water for drip and sprinkler irrigation, but no root infection was detected. This, however, was the same year that disease was not detected on the rhododendron foliage and propagule concentration was low during this period, so no conclusions should be drawn that root infections are not possible with stream water used for irrigation.

The natural levels of $P$. ramorum inoculum found in the stream varied from 0.0 to nearly 2.5 infective propagules/pear/liter, although during most irrigation periods it ranged from 0 to less than 1.0 propagules/ pear/liter. Propagules were reduced significantly, by $39 \%$, by the time they were pumped from the stream and applied to the plants during the period these two water sources were compared. The reduced propagule concentration at the sprinkler head can be explained by the movement of propagules through the tortuous irrigation system at considerable pressure. Others have observed lower numbers of Phytophthora species exiting irrigation systems than entering those systems (4). Catharanthus roseus were infected by spraying zoospore suspensions of Phytophthora nicotianae at pressures comparable to irrigation systems, and there was a consistent reduction in level of disease with increased application pressure regardless of the zoospore concentration (2). In our experiment, relatively low pressure sprinkler heads were used ( 245 to $280 \mathrm{kPa}$ [35 to $40 \mathrm{psi}$ ). However, in larger commercial nurseries, operating pressures can commonly be around 420 $\mathrm{kPa}(60 \mathrm{psi})$, and these higher pressures could reduce the propagule level even further and decrease disease occurrence.

Monitoring of streams with pear baits can be useful for detecting periods when infective propagules are present. With this fairly simple protocol, nursery operators could monitor stream propagule levels with the aid of a suitable laboratory and trained personnel either on site or through commercial services. When propagules are present or, at least, conditions are favorable for high propagule concentrations, nursery operators or landowners would need to sanitize the water before using it for irrigation purposes or use noninfested sources of irrigation water such as well water. Drip irrigation would greatly reduce the risk of foliar infection, but we do not have sufficient knowledge to suggest that root infections would not occur. Water sanitation could consist of various useful methods such as UV radiation, ozone, chlorination, or various particle and biological filtration methods (26). Greatest risk of disease could exist if hosts are sprinkler irrigated when inoculum levels are high as occurred in the spring in Santa Cruz County. Long hours of consecutive leaf wetness with cool temperatures would be particularly conducive to disease incidence.

\section{ACKNOWLEDGMENTS}

This research was possible with funding from the U.S. Department of Agriculture Forest Service Pacific Southwest Research Station. We thank Jennifer Davidson, University of Hawaii, Manoa, and Dave Rizzo, University of California, Davis, for guidance on pear baiting methods in the early stages of this research; Elizabeth Fichtner, University of California, Davis, for evaluating the rhododendrons for root infections; and Kat Kammeijer, University of California Cooperative Extension, Salinas, for her remarkable ability to manufacture large amounts of selective media.

\section{LITERATURE CITED}

1. Animal and Plant Health and Inspection Service (APHIS) Plant Protection and Quarantine (PPQ) Agency list of regulated hosts and plants associated with Phytophthora ramorum. USDA-APHIS. Published online.

2. Banko, T. J., Richardson, P. A., and Hong, C. X. 2006. Effects of zoospore concentration and application pressure on foliage blight of $\mathrm{Ca}$ tharanthus roseus caused by Phytophthora nicotianae. Plant Dis. 90:297-301.

3. Burnham, K. P., and Anderson, D. R. 1998. Model Selection and Inference: A Practical Information-Theoretic Approach. Springer-Verlag, New York.

4. Bush, E. A., Hong, C. X., and Stromberg, E. L. 2003. Fluctuations of Phytophthora and Pythium spp. in components of a recycling irrigation system. Plant Dis. 87:1500-1506.

5. Davidson, J. M., Werres, S., Garbelotto, M., Hansen, E. M., and Rizzo, D. M. 2003. Sudden oak death and associated diseases caused by Phytophthora ramorum. Plant Health Progress doi:10.1094/PHP-2003-0703-01-DG.

6. Davidson, J. M., Wickland, A. C., Patterson, H. A., Falk, K. R., and Rizzo, D. M. 2005. Transmission of Phytophthora ramorum in mixed evergreen forest in California. Phytopathology 95:587-596.

7. Erwin, D. C., and Ribeiro, O. K. 1996. Phytophthora Diseases Worldwide. American Phytopathological Society, St. Paul, MN.

8. Garbelotto, M., Svihra, P., and Rizzo, D. M. 2001. Sudden oak death syndrome fells three oak species. Calif. Agric. 55:9-19.

9. Gevens, A. J., Donahoo, R. S., Lamour, K. H., and Hausbeck, M. K. 2007. Characterization of Phytophthora capsici from Michigan surface irrigation water. Phytopathology 97:421-428.

10. Hong, C., Richardson, P. A., and Kong, P. 2002. Comparison of membrane filters as a tool for isolating pythiaceous species from irrigation water. Phytopathology 92:610-616.

11. Hwang, J. H., Oak, S. W., and Jeffers, S. N. 2008. Detecting Phytophthora ramorum and other species in Natural Ecosystems using baiting and filtration methods. Pages 55-58 in: Proc. Sudden Oak Death Third Science Symposium. S. J. Frankel, John T. Kliejunas, K. M. Palmieri, tech. coords. Pacific Southwest Research Station, Forest Service, U.S. Dep. Agric., Santa Rosa, CA.

12. McCulloch, C. E., and Searle, S. R. 2001. Generalized, Linear, and Mixed Models. John Wiley \& Sons, New York.

13. McIntosh, D. L. 1966. The occurrence of Phytophthora spp. in irrigation systems in British Columbia. Can. J. Bot. 44:1591-1596.

14. Murphy, S. K., Lee, C., Valachovic, Y., Mark, W., Jirka, A., Owen, D. R., and Rizzo, D. M. 2007. Monitoring Phytophthora ramorum distribution in streams within California watersheds. In: Phytophthoras in Forests \& Natural
Ecosystems, 4th IUFRO Working Group, Monterey, CA.

15. Nielsen, H. A. 2008. The R Foundation for Statistical Computing. Published online.

16. Parke, J. L., and Lewis, C. 2007. Root and stem infection of rhododendron from potting medium infested with Phytophthora ramorum. Plant Dis. 91:1265-1270.

17. Pettitt, T. R., Wakeham, A. J., Wainwright, M. F., and White, J. G. 2002. Comparison of serological, culture, and bait methods for detection of Pythium and Phytophthora zoospores in water. Plant Pathol. 51:720-727.

18. Ristaino, J. B., and Gumpertz, M. L. 2000 New frontiers in the study of dispersal and spatial analysis of epidemics caused by species in the genus Phytophthora. Annu. Rev. Phytopathol. 38:541-576

19. Rizzo, D. M., Garbelotto, M., Davidson, J. M., Slaughter, G. W., and Koike, S. T. 2002. Phytophthora ramorum as the cause of extensive mortality of Quercus spp. and Lithocarpus densiflorus in California. Plant Dis. 86:205214.

20. Roberts, P. D., Urs, R. R., French-Monar, R. D., Hoffine, M. S., Seijo, T. E., and McGovern, R. J. 2005. Survival and recovery of Phytophthora capsici and oomycetes in tailwater and soil from vegetable fields in Florida. Ann. Appl. Biol. 146:351-359.

21. SAS Institute. 2003. SAS Procedures Guide, version 9, release 9.1. SAS Institute, Inc. Cary, NC

22. Shishkoff, N. 2007. Persistence of Phy tophthora ramorum in soil mix and roots of nursery ornamentals. Plant Dis. 91:1245-1249.

23. Tjosvold, S. A., Chambers, D. L., and Blomquist, C. L. 2008. Seasonal Symptom Expression, Laboratory Detection Success, and Sporulation Potential of Phytophthora ramorum on Rhododendron and Camellia. Pages 101-107 in: Proc. Sudden Oak Death Third Science Symposium. S. J. Frankel, John T. Kliejunas, K. M. Palmieri, tech. coords. Pacific Southwest Research Station, Forest Service, U.S. Dep. Agric., Santa Rosa, CA.

24. Tjosvold, S. A., Chambers, D. L., Davidson, J. M., and Rizzo, D. M. 2002. Incidence of Phytophthora ramorum inoculum found in streams running through areas of high incidence of sudden oak death in Santa Cruz County. In: Sudden Oak Death Science Symposium: The State of Our Knowledge, Monterey, CA.

25. Tjosvold, S. A., Koike, S. T., and Chambers, D. L. 2008. Evaluation of fungicides for the control of Phytophthora ramorum infecting Rhododendron, Camellia, Pieris, and Viburnum. Online. Plant Health Progress doi:10.1094/ PHP-2008-0208-01-RS

26. Ufer, T., Posner, M., Wessels, H. P., and Werres, S. 2008. Untersuchungen zur Eliminierung von Phytophthora spp. aus Recyclingwasser in Baumschulen mit Hilfe von Filtrationsverfahren.; Studies on Phytophthora spp. elimination from recycling water in nurseries with filtration systems. Nachricht. Deutsch. Pflanzenschutz. 60:45-61.

27. Werres, S., Marwitz, R., Veld, W., De Cock, A., Bonants, P. J. M., De Weerdt, M., Themann, K., Ilieva, E., and Baayen, R. P. 2001. Phytophthora ramorum sp. nov., a new pathogen on Rhododendron and Viburnum. Mycol. Res. 105:1155-1165.

28. Werres, S., Wagner, S., Brand, T., Kaminski, K., and Seipp, D. 2007. Survival of Phytophthora ramorum in recirculating irrigation water and subsequent infection of Rhododendron and Viburnum. Plant Dis. 91:1034-1044.

29. Yamak, F., Peever, T. L., Grove, G. G., and Boal, R. J. 2002. Occurrence and identification of Phytophthora spp. pathogenic to pear fruit in irrigation water in the Wenatchee River Valley of Washington State. Phytopathology 92:1210-1217. 